Volume. 3 Nomor. 1

Periode: Januari - Juni 2019; hal. 28-36

p-ISSN : 2580-1112; e-ISSN : 2655-6669

Copyrighr @2019

Jurnal Ilmiah Keperawatan Orthopedi

Penulis memiliki hak cipta atas artikel ini

(JIKO)

journal homepage: https://ejournal.akperfatmawati.ac.id

\title{
Pemenuhan Kebutuhan Kenyamanan Pada Anak Dengan Ruam Popok Melalui Penerapan Virgin Coconut Oil (VCO) Dengan Pendekatan Teori Comfort Kolcaba
}

\author{
Ngatmi $^{1}$, Nani Nurhaeni ${ }^{2}$, Dessie Wanda ${ }^{3}$ \\ Program Spesialis Keperawatan, Fakultas Ilmu Keperawatan, Universitas Indonesia, Depok \\ Fakultas Ilmu Keperawatan, Universitas Indonesia, Depok
}

\begin{abstract}
Abstrak
Ruam popok merupakan reaksi inflamasi akut pada daerah kulit perianal yang umum terjadi pada anak-anak. Tujuan dari studi kasus ini adalah melakukan pemenuhan kebutuhan kenyamanan pada anak yang mengalami gangguan integritas kulit dengan implementasi virgin coconut oil dengan pendekatan Teori Comfort Kolcaba. Hasil implementasi pada lima kasus terpilih menunjukkan bahwa terjadi perbaikan pada masalah keperawatan kerusakan integritas kulit dan nyeri akut yang dialami anak dengan ruam popok. Implementasi virgin coconut oil dapat memperbaiki kerusakan jaringan yang terjadi. Penerapan virgin coconut oil melalui pendekatan Teori Comfort Kolkaba dapat diterapkan pada anak dengan gangguan kenyamanan.
\end{abstract}

Kata Kunci: Virgin Coconut Oil, Nyeri, Kerusakan Integritas Kulit, Dan Teori Comfort Kolkaba

\begin{abstract}
Diaper rash is an acute inflammatory reaction in the perianal skin areas that commonly occur among children. The purpose of this case study is to meet the needs of comfort among children experienceimpaired skin integrity with application of virgin coconut oil with Comfort Kolcaba Theory approach. The result of the application of the five selected cases demonstrated that improvements in to skin integrity and reduced acute pain experienced by children with diaper rash. Implementation of virgin coconut oil can repair the tissue damage that. Application of virgin coconut oil through Comfort Kolkaba Theory approach can be applied to children with disorders of comfort.
\end{abstract}

Keywords: Virgin Coconut Oil, Pain, Damage To Skin Integrity, And Theory Of Comfort Kolkaba

1,2,3 e-mail: mamito.ngatmi@gmail.com 


\section{Pendahuluan}

Ruam popok (diaper rash, diaper dermatitis, napkin dermatitis, nappy rash, ammonia dermatitis) adalah reaksi inflamasi akut pada daerah kulit perianal yang umum terjadi pada anak-anak (Heimall, Storey, Stellar, \& Davis, 2012). Ruam popok terjadi karena kulit anakanak lebih tipis daripada orang dewasa, menghasilkan sekresi sedikit, dan lebih rentan terhadap iritasi dan infeksi (Singleton, 2007). Insiden ruam popok paling banyak terjadi pada anak usia 8 hingga 12 bulan (Wolf, Wolf, \& Tuzun, 2001).

Angka kejadian ruam popok bervariasi antara 4-35\% dalam 2 tahun pertama kehidupan dan meningkat tiga kali lipat pada bayi dengan diare (Cadelina, 2010). Di Indonesia, angka kejadian ruam popok diperkirakan mencapai 30\% (Paramita, 2014).

Ruam popok terjadi sebagai proses interaksi dari kontak yang terlalu lama terhadap kelembaban dan agen iritan (Cadelina, 2010). Kelembaban dan enzim feses (urease, protease, lipase) merupakan iritan utama ruam popok (Nield \& Kamat, 2007). Aktivitas lipase dan protease sangat meningkat dengan percepatan aktivitas gastrointestinal pada bayi yang mengalami diare. Selain itu, paparan kulit secara terus menerus pada lingkungan basah menyebabkan maserasi (pelunakan) dari stratum korneum, sehingga stratum korneum lebih rentan terhadap kerusakan (Cadelina, 2010).

Minyak kelapa murni, virgin coconut oil (VCO) adalah salah satu bentuk barrier yang dapat dimanfaatkan untuk penatalaksanaan ruam popok. VCO adalah minyak murni yang dihasilkan dari pengolahan daging kelapa (Carandang, 2009). Sachs, Eichel, dan Asskali (2002) melakukan penelitian tentang kandungan VCO sebagai agen penyembuhan luka yang digunakan oleh kelompok etnis di Ngada, Flores. Hasil penelitian menunjukkan bahwa VCO memiliki struktur biokimia yang baik untuk penyembuhan luka karena mengandung asam lemak jenuh rantai pendek.

Kolcaba memandang bahwa kenyamanan merupakan kebutuhan dasar seseorang individu yang bersifat holistik, meliputi kenyamanan fisik, psikosoial, sosiokultural, lingkungan. Kenyamanan fisik berhubungan dengan sensasi tubuh dan homeostasis meliputi penurunan kemampuan tubuh merespon suatu penyakit atau prosedur invasif.

Kenyamanan psikososial dikaitkan dengan keharmonisan hati dan ketenangan jiwa, yang dapat difasilitasi dengan memenuhi kebutuhan interaksi dan sosialisasi dengan orang-orang terdekat selama perawatan dan melibatkan keluarga secara aktif dalam proses kesembuhan anak. Kebutuhan sosiokultural berhubungan dengan hubungan interpersonal, keluarga dan masyarakat, meliputi kebutuhan terhadap informasi kepulangan (discharge planning) perawatan yang sesuai dengan budaya pasien (Kolcaba 2005).

\section{Metode}

Studi kasus dilakukan di RSUPN Cipto Mangunkusumo dan RSAB Harapan Kita pada anak dengan gangguan integritas kulit yaitu ruam popok. Data diperoleh melalui penerapan asuhan keperawatan dengan penerapan Teori Kolkaba.

\section{Hasil Penelitian \\ Kasus Pertama}

Anak AZ jenis kelamin perempuan dirawat dengan diagnosis medis bronkopneumonia post morbili dan ada diare perbaikan. Anak $\mathrm{Az}$ pernah dirawat dengan bronkiolitis bulan Januari tangal 18-25 dirawat di ruang icu RSAB Harapan kita, pindah keruang rawat Gambir dirawat selama 1minggu, lalu pulang. Tanggal 7-2-2016 demam, keluar merah-merah diseluruh tubuh, batuk sesak nafas lalu dibawa ke RSAB Harapan Kita dan dirawat di ruang Gambir. Pada tgl 222-2016 hasil pengkajian didapatkan hasil 
kesadaran kompos mentis sesak nafas. Pemeriksaan fisik bentuk kepala bulat, rambut tipis, bibir pecah-pecah, muka datar, nafas cuping hidung, kulit merahmerah, terdapat ruam popok. Berat badan $11,4 \mathrm{~kg}$, panjang badan $81 \mathrm{~cm}$, linkar perut $52 \mathrm{~cm}$, lingkar lengan $16 \mathrm{~cm}$. tandatanda vital suhu 39 derajat celsius, nadi $132 \mathrm{kali} / \mathrm{menit}$, pernafasan $38 \mathrm{kali} / \mathrm{menit}$, tekanan darah $100 / 60 \mathrm{mmHg}$, sekala nyeri 1-3 dinilai dengan menggunakan scoring nyeri FLACC Pain Scale.

Masalah keperawatan utama yang ditem ukan adalah bersihan jalan nafas tidak efektif, gangguan integritas kulit, gangguan rasa nyaman nyeri. Tindakan keperawatan yang dilakukan berdasarkan intervensi comfort, meliputi tiga tipe yaitu tehnik tindakan yang mempertahankan homeostasis, coaching meliputi tindakan yang didesain menurunkan kecemasan, dengan memberikan informasi, memberikan informasi dan pengajaran perawatan menggunakan VCO, comforting meliputi menjaga lingkungan tetap nyaman, alat tenun pakaian harus kering dan bersih.

$$
\text { Tindakan untuk mengatasi }
$$

bersihan jalan nafas tidak ifektif, mengatur posisi, melonggarkan pakaian, mengukur prekuesi, suara, pola nafas, adanya sianosis, setiap 4 jam. Memberikan inhalasi normasalin 0,9\% dicampur ventolin 1 ampul, melakukan perkusi dan vibrasi. Masalah gangguan integritas kulit, teknikal dilakukan, memandikan dua kali sehari dengan air hangat, sabun yang lembut, menjaga kebesihan pakaian tetap bersih dan kering, coaching mengajarkan ibu cara perawatan kuli dan memandikan saat anak sakit, comforting: menjaga pakaian tetap bersih dan kering.

Masalah gangguan rasa nyaman nyeri, dilakukan tindakan keperawatan ruam popok teknikal: menggunakan VCO empat kali sehari, coaching melibatkan orang tua untuk melakukan, sebelumnya telah diajarkan pakaian tetap kering ganti popok setian basah, comforting menjaga popok tetap kerin ganti popok setiap kali basah.

Evaluasi dilakukan setelah 3 hari perawatan, didapatkan suara nafas ronkhi masih ada, gangguan integritas kulit teratasi, gangguan rasa nyaman teratasi dengan kriteria kulit bersih tidak ada ruam, pasien dapat istirahan dengan tenang, tidah menangis saat diganti popok, tidur cukup, anak ceria.

\section{Kasus Kedua}

Anak MU laki-laki usia 8 bulan dirawat di ruang gambir tanggal 5 Maret 2016 dengan diagnosis medis febris suspek ensefalitis, diare dehidrasi ringan. Hasil pengkajian diperoleh data dari orang tua dan pemeriksaan fisik. Ibu pasien mengatakan anaknya sakit demam sudah 3 hari, pernah dilakukan lumbal pungsi hasilnya dijelaskan tidak ada masalah, hasil CT scan terjadi subarahnoid efusi dengan ventrikulomegali minimal.

Selain demam 1 hari yang lalu buang air besar 13-20 kali sehari suara sampai serak, bibir kering, makan minum sedikit, anak rewel, ada lencet di anus tidak ada penurunan berat badan. Hasil pemeriksaan fisisk kesadaran compos mentis, anak lemes, turgor kembali kurang dari 2 detik, membran mukosa kering, ubun-ubun datar, anak rewel minum mau, terpasang infus 2A 15 tetes per menit, tetesan lancar. Suhu 37 derajad celsius, nadi $116 \mathrm{x} /$ menit, pernafasan $28 \mathrm{x} /$ menit tekanan darah $94 / 49 \mathrm{mmHg}$, berat badan $7 \mathrm{~kg}$, panjang badan $75 \mathrm{~cm}$, lingkar lengan $14 \mathrm{~cm}$, lingkar perut $45 \mathrm{~cm}$ lingkar dada $46 \mathrm{~cm}$.

Masalah keperawatan utama yang dirumuskan adalah kekurangan volume cairan, gangguan integrtas kulit, gangguan rasa nyaman nyeri. Masalah kekurangan volume cairan Tindakan keperawatan yang dilakukan: teknikal pemberian cairan melalui NGT susu low laktosa $8 \mathrm{x}$ $90 \mathrm{ml}$ diberikan setiap 3 jam, infus 2A 12 tetes/menit. tetesan lancar, memonitor tanda-tanda dehidrasi, tanda-tanda vital, memonitor balance cairan setiap 8 jam, coaching: mengajarkan kepada orang tua 
tanda-tanda kurang volume cairan, cara memberikan minum, tindakan yang dilakukan untuk mengatasi kekurangan cairan, comfothing menyendawakan pasien dan mengatur posisi.

Pada masalah gangguan integritas kulit dan gangguan rasa nyaman dilakukan perawatan teknikal: melakukan perawatan dengan menggunakan VCO 4 kali sehari mengganti pakaian yang basah, coaching mengajarka cara melakukan perawatan ruam popok dengan VCO $4 \mathrm{x} /$ hari, cara menilai rasa nyaman pasien, comforting: menjaga pakaian tetap kering ganti popok setiap kali BAB/BAK, lingkungan yang aman dan nyaman.

Evaluasi dilakukan setelah 3 hari perawatan hasilnya turgor kuli kembali kurang dari 2 detik, BAB $1 \mathrm{x}$ sehari konsistensi lembek, balance cairan seimbang, tidak ada tanda-tanda dehidrasi. Keadaan kulit kembali normal, merah-merah disekitar anus sembuh.Anak dapat istirahat dengan tenang, tidak menangis saat diganti popok, tidur tidak gelisah.

\section{Kasus Ketiga}

Anak SAG usia 6 bulan dirawat gedung A lantai 1 RSCM sejak 24 Maret 2016 dengan diagnosis medis diare melanjut dehidrasi sedang, suspek HIV, gizi buruk marasmik. Hasil anamnesa ibu pasien mengataka anknya perkembangannya terlambat, anak sakit sejak usia 2 bulan, batuk, pilek, diare pernah dirawat di rumah sakit, dinyatakan hasilnya HIV.

Saat dikaji orang tua mengatakan anaknya BAB $20 \quad x$ sehari dengan konsistensi cair, ada lendir, warna kuning. Pemeriksaan fisik anak tampak kurus, kepala bulat rambut tipis, konjungtiva pucat, kulit putih. Pernafasan normal tidak ada tarikan dinding dada, ekstremitas normal gigi sudah ada 4. Suhu 37,5 derajat celcius, nadi $132 \mathrm{x} /$ menit, pernafasan $34 \mathrm{x} /$ menit, berat badan $4,8 \mathrm{~kg}$, panjang badan $64 \mathrm{~cm}$, lingkar lengan 9 $\mathrm{cm}$, lingkar dada $43 \mathrm{~cm}$, lingkar perut 43 $\mathrm{cm}$, terdapat ruam popok sangat luas ibu mengatakan sudah diobati selama 1 bulan belum ada penyembuhan. Hasil penunjang thoraks foto kesan bronkopneumonia, hasil laboratorium hemoglobin 7,99g/dl, leukosit 14900 ribu g/dl/, trombosit 230 $\mathrm{ribu} / \mu$, LED 60. CD4 3520/ $\mu 1$,dalam \% L24\%, diet cair 8x60 ml susu BBLR free laktosa diberikan melalui NGT, ditambah makanan padat bubur cereal $4 \mathrm{x}$ sehari.

Masalah keperawatan yang prioritas antara lain, bersihan jalan nafas tidak efektif, ketidakseimbangan nutrisi kurang darikebutuhan, gangguan rasa nyaman nyeri. Masalah bersihan jalan nafas tidak efektif telah dilakukan tindakan keperawatan, tehnikal mengatur posisi, memberikan inhalasi Nacl $0,9 \%$ ditambah ventolin 1 ampul, coaching mengajarkan ibu cara memberikan minum dan makan, mengatur posisi tanda-tanda sesak nafas suara nafas yang normal dan tidak normal, comforting posisikan semipowler untuk optimalkan ventilasi.

Masalah nutrisi dilakukan tindakan keperawatan tehnikal pemberian nutrisi cair melalui NGT susu BBLR free laktosa 8x60, coaching: mengajarka ibu untuk mempberikan makan dan minum melalui NGT, comforting menyendawakan anak setelah selesai minum dan makan. Masalah gangguan integritas kulit dilakukan perawatan tehnikal: menggunakan VCO dioleskan 4x/hari, coaching: mengajarkan kepada ibu untuk melakukan perawatan ruam popok dengan VCO $4 \mathrm{x} /$ hari, comporting jaga lingkungan dan pakaian tetap bersih dan kering, mengganti popok setiap kali basah.

Evaluasi dilakukan setelah 3 hari perawatan dengan hasil, pasien masih batuk, suara nafas ronchi ada, masalah nutrisi belum ada peningkatan berat badan, muntah tidak ada, BAB 9x/hari, masalah gangguan integritas kulit/gangguan rasa nyaman, kulit merah berkurang, papul tidak ada, saat diganti popok tidak menangis. Disimpulkan masalah keperawatan 1,2 belum teratasi, masalah 3 teratasi. 


\section{Kasus Keempat}

Anak AD dirawat diruang anak RSCM karena kejang demam komplek dan diare, masuk melalui IGD sejak tanggal 12 april 2016 pukul 23, dilakukan pengkajian tanggal 13 April 2016 pukul 9 WIB. Orang tua pasien mengatakan anaknya demam dan kejang sejak tanggal 12-4-2016 pukul 11 pagi, lamanya kejang 1-5 menit, frekuensi $3 x$ lalu dibawa ke rumah sakit untuk mendapatkan pertolongan. Anak pernah dirawat tgl 1711-2015 s/d 19=11 2015 karena kejang, waktu itu pulang atas permintaan keluarga dan pengobatan belum selesai, anak terlambat perkembangannya.

Hasil CT scan menunjukkan kepala terjadi penebalan soft tissue region parietal kiri yang tampak menyangat paska kontras, disertai defek regioparietal kiri sesuai gambaran abses soft tissue region parietal kiri tidak tampak kelainan intra kranial. Tulang kalvaria intak tidak tampak lesi titik/destruktif. Hasil laboratorium hemoglobin $7,15 \mathrm{~g} / \mathrm{dl}$, hematokrit $22,8 \%$, leukosit $724 \mathrm{ribu} / \mu 1$, trombosit 307000, gula darah sewaktu $194 \mathrm{mg} \%$.

Pemeriksaan fisik didapatkan pasien berbaring tampak gemuk, kulit putih, kepala bulat ada luka dikepala tertutup kasa, konjungtiva agak anemis, bentuk dada, perut, ekstremitas normal, kulit ada ruam popok disekitar anus, derajat 2, anak berteriak saat diganti popok. Suhu 38,2 derajat celsius, nadi $128 \mathrm{x} /$ menit, pernafasan $30 \mathrm{x} / \mathrm{menit}$, tekanan darah $96 / 54 \mathrm{mmHg}$, saturasi oksigen $98 \%$. Terpasang infus vena dalam pada daerah femorali kiri, tidak ada kemerahan tetesan infus lancer. Pengobatan yang didapat yaitu infus KaEn 3B mentenens 12 tete/mt, zink $1 \times 20 \mathrm{mg}$, parasetamol $2 \times 70 \mathrm{mg}$, depaken syrup $2 \times 1,5 \mathrm{ml}$, cefiksim sirup $2 \times 2 \mathrm{ml}$.

Masalah utama yang prioritas adalah gangguan perfusi jaringan cerebral, resiko injuri, gangguan integritas kulit. Tindakan keperawatan yang dilakukan mengatasi tehnikal memonitor tingkat kesadaran, mengatur posisi, memberikan obat depaken secara dengan 7 benar, melakukan evaluasi adanya kejang berulang setia 2 jam, jangan memasukkan apapun saat kejang berlangsung, tempatkan pasien pada tempat yang aman tempat tidur yang ada penghalangnya, jangan ditinggalkan sendirian, beri kompres hangat, melakukan perawata ruam popok dengan menggunakan $\mathrm{VCO}$ 4x/hari. Coaching mengajarka kepada ibu pasien untuk membantu observasi adanya kejang, selalu memasang penghalang tempat tidur untuk mancegah jatuh, jangan memasukan benda apapun saat anak kejang, cara membersihkan dan melakukan parawatan ruam popok. Comforting posisikan anak pada tempat tidur yang tidak tinggi, aturudara ruangan yang tidak terlalu dingin dan tidak panas, pakaian, alat tenun selalu kering, ganti pakaian setiap kali basah.

Evaluasi setelah dilakukan keperawatan selama 3 hari, anak tidak kejang, kesadaran kompos mentis, demam tidak ada, orang tua selalu memasang penghalang tempat tidur, sehingga anak tidak terjadi injuri, kulit yang ruam sembuh tidak ada kemerahan, anak saat diganti popok tidak menangis ibu dapat berpartisipasi dalam perawatan pasien dengan optimal. Ketiga masalah keperawatan teratasi pasien dari dokter diizinkan pulang.

\section{Kasus Kelima}

Anak A laki-laki usia 6 bulan dirawat diruang Gambir RSAB Harapan kita, masuk melalui IGD tanggal 18-32016 pukul 01 WIB, dengan keluha diare sejak 4 hari sebelum masuk rumah sakit, prekuensi BAB 4-8x/hari, jumlah lebih kurang 1 gelas setiap BAB, banyak airnya,ingus tidak ada, BAK spontan 47x/hari. Anak rewal, ada demam, batuk, nafas bunyi. Pemeriksaan fisik didapatkan kesadaran compos mentis, anak berbaring tampak sehat, kepala bulat kulit putih agak anemis, rambut tipis, membrane mukosa kering anak tampak kehausan, turgor kembali kurang dari 2 detik, 
ekstremitas normal, terpasang infus pada tangan kiri KaEn 3B 12 tetes/menit. Ada tarikan dinding dada, pernafasan $34 \mathrm{x} / \mathrm{mt}$, nadi $134 \mathrm{x} / \mathrm{mt}$, suhu 38 derajat celsius, tekanan darah 96/54 mmHg. Bab cair tidak ada lendir dan darah. Hasil laboratorium hemoglobin $8,5 \mathrm{~g} / \mathrm{dl}$, hematokrit 35\%, leukosit 12,15 ribu g/dl, trombosit290 $\mathrm{ribu} / \mu \mathrm{l}$, LED $33 \mathrm{~mm} / \mathrm{jam}$. Hasil thoraks foto kesan bronkopneumonia. Perkembangan anak sudah bisa tengkurap tetapi belum bisa balik sendiri. Anak merintih dan gelisah, menangis saat diganti popok, ada ruam popok.

Masalah keperawatan yang prioritas dirumuskan yaitu: bersihan jalan nafas tidak efekti, gangguan kebutuhan cairan, gangguan integritas kulit. Tindakan keperawatan yang dilakukan teknikal: mengatur posis semi powler, memberikan inhalasi, perkusi vibrasi, saksion, memberkan pakaian yang longgar, memonitor tanda-tanda dehidrasi setiap 8 jam, intake output, tetesan infus, tanda-tanda vital, memberika minum pedialit setai kali BAB, malakukan perawatan ruam popok dengan VCO, evaluasi kenyamanan setiap 6 jam. Coaching: mengajarkan kepada orang tua tentang pernafasan yang normal dan tidak norma, cara mengenali tanda-tanda kurang cairan, memberikan minum yang aman, perawatan ruam popok dengan menggunakan VCO. Comforthing: mengatur posisi semi powler, memberri posis yang aman saat memberi minum, menyendawakan setelah memberi minum, menjaga pakaian tetap kering, mengganti pakaian setiap basah.

Evaluasi dilakukan setelah 3 hari intervensi batuk berkurang, sesak nafas tidak ada, tidak ada tarikan diding dada ronkhi tidah ada, pernafasan 30x/menit, nadi 116x/menit suhu 37 derajat celcius, BAB 1x sehari konsistensi lembek tidak ada tanda-tanda dehidrasi, ruam popok masih ada grade 1 . Dokter merencanakan thoraks foto ulang tetapi keluarga menolak karena biaya tidak ada, dan ackhirnya pasien dibawa pulang atas prmintaan keluarga, pada hari ke lima melakukan kunjungan rumah untu evaluasi integrtas kulit/ruam popok, ibu pasien mengatakan anaknya tidak menangis saat diganti popok dan ruam popok sudang sembuh. Kulit sekitar anus utuh, dan tidak menangis saat diganti popok, tidur tidak gelisah. Masalah keperawatan 1,2,3 teratasi, saat kunjungan rumah dilakukan edukasi tentang kapan pasien kembali segera ke rumah sakit, kapan harus control, perawatan selama dirumah cara meningkatkan kenyamanan pasien.

\section{Pembahasan}

Pengkajian kenyamanan terkait pengalaman fisik dilakukan melalui wawancara, pemeriksaan fisik dan observasi terkait dengan keluhan, sikap tubuh, prilaku yang menunjukan ketidaknyamanan pasien. Data yang diperoleh melalui observasi, wawancara dan pemeriksaan fisik pada kelima pasien kelolaan dengan pasien bervariasi, jenis kelamin, usia dan diagnosis medis.

Pengkajian kenyamanan dilakukan dengan melakukan observasi respon pasien dengan menggunakan nursing comfort measure (NCM) yang diukur dengan tiga hal yaitu: fisik, fisologis dan persepsi perawat. Fisik meliputi postur tubuh, pola tidur, ekspesi, pola istirahat, menangis, derajat ruam popok. Fisiologis meliputi pernafasan, denyut jantung, sturasi dan tekanan darah.Persepsi perawat meliputi menganalisa dari fisik dan psikologis.

Pada perawatan ruam popok yang dilakukan pada anak MF laki-laki usia 6 bulan diagnosis medis diare dan pneumonia dan perkembangan lambat skor nyeri berdasarkan FLACC skor 4 sampai 6 dengan penjabaran yaitu: anak rewel, menyeringai, tidur gelisah, menunjukan lokasi nyeri. Kondisi yang sama juga dapat dilihat pada anak AZ perempuan usia 14 bulan diagnosis medis diare dan pneumonia dan perkembangan 
post morbili riwayat down sydrom dengan skor nyeri 4 sampai 6 dengan penjabaran yaitu: gelisah, menyeringai, menangis saat diganti popok. Pada bayi MU laki-laki 8 bulan diagnosa medis diare dan suspek ensepalitis skor nyeri 1 sampai 3 dengan penjabaran yaitu: nyeri ringan, dapat berkomunikasi dengan baik, dapat beristirahat dengan cukup.

Anak SAG laki-laki usia 6 bulan dengan diagnosis medis diare dan suspek HIV dan gizi buruk marasmus skor nyeri 4 sampai 6 dengan penjabaran yaitu: merintih, menyeringai, istirahat kurang, menunjukan lokasi nyeri, menangis di saat ganti popok. Anak AD laki-laki usia 13 bulan diagnosis medis kejang demam kompleks dan diare skor nyeri 4 sampai dengan 6 yaitu: merintih, menangis saat diganti popok, menunjukan lokasi nyeri.

Pengkajian psikospritual pada pasien lima kasus kelolaan ini dikaitkan ketenangan jiwa dan dikaji melalui wawancara orang tua residen tidak dapat mengkaji kebutuhan rasa nyaman psikospiritual yang lebih dalam karena pasien bayi belum dapat berkomunisakasi secara verbal, sehingga residen menemukan kenyamanan psikospritual pada orang tua pasien. Pada kasus pasien MF didapat data ibu pasien kurang optimal dalam memberikan perawatan ruam popok pada anak.Kondisi kenyamanan pada orang tua dapat menularkan ketidaknyamanan kepada anaknya (Horison, 2010).

Pengkajian ini mencakup
pengkajian intrapersonal dan interpersonal, interaksi anak dan orang tua dikaji dalam pengkajian kenyamanan, pada kasus ini interaksi orang tua tidak optimal karena ayah selama anak dirumah sakit tidak pernah datang untuk mengunjungi.Interaksi orang tua dengan pasien melalui sentuhan sangat mempengaruhi perkembangan psikologis, biokimia dan fungsi psikologis (William \& Simon, 2010).

Pengkajian lingkungan pada teori comfort ini mencakup respon adaptasi anak dan kelurga terhadap lingkungan fisik di Rumah Sakit. Lingkungn yang berbeda dapat menjadi stressor tersendiri bagi anak dan keluarga. Stressor tersebut dapat berupa cahaya, kebisingan, suhu dan pasien sekitarnya, apabila anak dan keluarga tidak dapat beradaptasi maka akan timbul ketidaknyamanan (Kolcaba, 2003).

Diagnosis keperawatan dari pengkajian yang dilakukan dapat dirumuskan diagnosis keperawatan pada setiap kasus kelolaan. Diagnosis keperawatan 'nyeri' ini muncul diakibatkan gangguan integritas kulit. Kondisi ini sejalan dengan penilitian yang saya lakukan tahun 2015, dilakukan pada 18 sampel kelompok intervensi dilakukan perawatan dengan menggunakan virgin cococnut oil dan 18 sempel kelompok kontrol tidak menggunkana. Dengan hasil ada pengaruh terhadap derajat ruam popok, pada kelompok intervensi sembuh dalam waktu 3-5 hari, pada kelompok kontrol sembuh dalam waktu 15 hari.

Intervensi keperawatan yang dilakukan berfokus pada peningkatan rasa nyaman anak dan keluarga. Kolcaba memegang prinsip bahwa perawat harus berinteraksi dengan pasien secara komprehensif, sehingga mengtahui keluhan pasien terutama dalam hal untuk mengatasi kenyamanan.

Intervensi keperawatan mempunyai tiga tipe yang dikelompokan berdasarkan kebutuhan rasa nyaman yaitu technical, coaching, comforthing. Teknik untuk mengatasi kebutuhan kenyamanan fisik, coaching untuk memberikan pemahaman kepada keluarga tentang kebutuhan rasa nyaman sosiokultural, dan comfoting untuk memberikan kenyamanan psikospiritual dan lingkungan. Intervensi keperawatan telah dikelompokan sehingga memudahkan untuk menyusun intervensi sesuai diagnosis keperawatan yang telah diidetifikasi sebelumnya dengan menggunakan taksonomi Comfort Kolcaba. 
Hockenberry dan Wilson (2009) menjelaskan bahwa penatalaksanaan nyeri dapat diberikan analgatik, namun harus didahului oleh pengkajian nyeri. Pada kelima kasus kelolaan, intervensi technical dibuat untuk mengatasi masalah yang berhubungan dengan kenyamanan fisik, seperti mengkaji skala nyeri dengan alat pengkajian nyeri, observasi perubahan, fisiologis, dan perilaku anak.catat respon verbal dan non verbal, kolaborasi untuk pemberian analgeti, perawatan dengan menggunakan virgin cococnut oil.

Intervensi coaching yang dilakukukan adalah memberikan edukasi kepada keluarga meningkatkan pengetahuan ibu dalam mengatasi, perubahan kenyamanan pasien dan dapat melakukan perawatan secara mandiri untuk menggunakan virgin coconut oil untuk meningkatkan kenyamanan pasien.Comforthing intevensi yang dilakukan mengatur lingkungan yang kondusif, memberikan pakaian yang tetap kering, ibu dianjurkan mendampingi pasien setiap dilakukan tindakan.

Pada tahap implementasi, residan melakukan intervensi yang telah direncanakan dengan melibatkan orang tua pada semua kasus kelolaan. Implementai yang dilakukan untuk mengurangi rasa nyeri pada pasienyang mengalami gangguan integritas kulit dilakukan tindakan keperawatan dengan menggunakan virgin coconut oil. Pada pasien MF implementasi dengan memfasilitasi orang tua untuk belajar dan melakukan perawatan gangguan integritas kulit pada pasien secara mandiri. Sebelum orang tua melakukan tindakan tersebut, residen memberikan edukasi tentang cara perawatan gangguan integritas kulit dengan virgin coconut oil.

Kondisi ini menyebabkan terjadinya interaksi orang tua dan anak, petugas kesehatan, sehingga setiap melakukan prosedur dapat berjalan dengan lancar sesuai dengan tujuan yang telah dirumuskan (family centered care) dapat di aplikasikan. Kehadiran orang tua berdampak positif terhadap perkembangan otak, kognitif, dan psikomotor pada bayi (Westrup, 2014).

Setelah dilakukan implementasi keperawatan yang dilakukan pada pasien yang mengalami gangguan integritas kulit dengan perawatan menggunakan virgin coconut oil. Selanjutnya evaluasi keperawatan didapatkan hasil gangguan kenyamanan dapat teratasi dalam $3 \times 24$ jam, dengan skala nyeri 4-6 menjadi skala 0 .

Manifestasi klinik dari pasien yang mengalami ruam popok dikeluhkan oleh orang tua adalah anak rewel, istirahat kurang, rewel saat diganti popok, dan ada kemerahan didaerah bokong. Tetapi ada orang tua yang tidak memiliki keluhan karena menganggap ruam popok bukanlah masalah dan menganggap rewel itu hal yang biasa terjadi pada anak yang sakit. Nyeri merupakan masalah yang teridentifikasi dan dirasakan oleh anak yang mengalami ruam popok. Hal ini disampaikan oleh orang tua yang menunggu anak selama dirawat.

Evaluasi dilakukan untuk mengetahui perkembangan tingkat kenyamanan pasien sebelum dan sesudah dilakukan perawatan kulit dengan menggunakan virgin coconut oil (VCO) serta evaluasi perbandingan dengan yang menggunakan obat lain.

Pada pasien yang tidak diberikan intervensi pemberian Virgin Coconut Oil, yaitu sebanyak 5 (lima) pasien, waktu penyembuhan ruam popok lebih lama. Sebanyak 3 (tiga) pasien sembuh dalam waktu 2 minggu, 1 (satu) pasien sembuh dalam waktu 1 minggu, dan 1 pasien belum mengalami penyembuhan karena tidak mendapatkan tata laksana ruam popok. Hal ini menunjukkan bahwa pemberian virgin coconut oil meningkatkan efektivitas perawatan kulit pada pasien ruam popok dan mengurangi ketidaknyamanan yang dirasakan oleh pasien. 


\section{Kesimpulan dan Saran}

Aplikasi Teori Comfort Kolcaba pada anak dengan gangguan integritas kulit mencakup semua aspek asuhan keperawatan meliputi pengkajian, diagnosis keperawatan, intervensi dan evaluasi. Pasien yang diberikan intevensi Virgin Coconut Oil menunjukkan waktu penyembuhan ruam popok yang lebih cepat dibandingkan pasien yang tidak mendapatkan intervensi Virgin Coconut Oil. Lama hari penyembuhan pada pasien dengan Virgin Coconut Oil adalah 3-5 hari sedangkan pada pasien yang tidak diberikan Virgin Coconut Oil selama 1-2 minggu.

Rekomendasi dalam studi kasus ini adalah aplikasi Teori Comfort Kolcaba dapat diaplikasikan pada anak dengan gangguan integritas kulit yang mengalami masalah nyeri.

Keterlibatan keluarga sangat diperlukan untuk efektivitas pemberian asuhan keperawatan, terutama dalam penerapan pemberian virgin coconut oil pada masalah gangguan integritas kulit.

\section{Daftar Putaka}

Alligood, M.R., \&Tomey, A.M. (2006). Nursing theory, utilization \&application. (3rded), USA: Mosby Elsevier.

Corwin, E.J. (2001). Buku saku patofisiologi, alih bahasa: Bramh U Pedit. Jakarta: EGC.

Hockenberry.M\& Wilson.(2009). Wong's essensials of pediatric nursing. St.Louise Missouri: Mosby Essiver.

Potts, N.L., \& Mandleco, B.L. (2007). Pediatric nursing: Caring for children and their families. Clifton park, New York: Thomson Delmar Learning.

Wong, D.L., Hockenberry, M., Wilson, D., Wikelstein, M.L., Schwartz, P. (2009). Buku ajar keperawatan pediatrik, volume 1. Jakarta: EGC.
Wong, D.L. (2003). Nursing care of infants and children,(7th edition), volume 2. St.louis: Mosby. 